\title{
THE MALINITE PROCESS FOR THE PRODUCTION OF SILLIMANITE REFRACTORIES
}

By A. Malinovszky

\section{The Theory of the Process}

The Malinite process is a method of producing sillimanite refractories. The object of the process is to produce an extremely refractory material, having a neutral quality, for metallurgical structures, such as open-hearth and electric furnaces, converters, crucibles, and molds, where high temperatures and destructive slags are employed; also for the chemical industry and for chemical stonewares.

By this process any aluminous rocks or minerals can be converted into a stable compound of aluminum monosilicate, known in the ceramic art as sillimanite, and which resists high heat and slag. I have discovered that if aluminum silicate such as clays, halloysite, and other like aluminous rocks or minerals of wide occurrence are smelted in a cupola furnace (which I have specially designed for this purpose) together with a suitable reducing agent in proper amount, it is possible to regulate the volatilization of the silica by proportioning the amount of the reducing agent, so that it shall be sufficient to reduce all the silica, or to produce only a fractional reduction of the silica to any desired amounts, leaving only a part of the silica unreduced so as to convert all the charge into sillimanite, or only a part into sillimanite and the rest into fused quartz glass. It should be mentioned at this point that sillimanite or corundum does not combine with fused silica, nor with amorphous silica when it is available.

Preparing the materials for the fusing and charging the cupola are as follows: I take, for instance, the crushed raw material, and mix therewith a suitable reducing agent, as carbon, in the molecular proportion to the silica content in the rock or minerals as indicated in the following equations: 
$2\left(\mathrm{Al}_{2} \mathrm{O}_{3}+{ }_{2} \mathrm{SiO}_{2}\right)+6 \mathrm{Fe}_{2} \mathrm{O}_{3}+39 \mathrm{C}=\mathrm{Al}_{4} \mathrm{C}_{3}+{ }_{4} \mathrm{Fe}_{3} \mathrm{SiC}+{ }_{32} \mathrm{CO}$ $\mathrm{Al}_{4} \mathrm{C}_{3}+{ }_{4} \mathrm{Fe}_{3} \mathrm{SiC}+\mathrm{O}_{21}={ }_{2} \mathrm{Al}_{2} \mathrm{O}_{3}+{ }_{4} \mathrm{SiO}_{2}+{ }_{12} \mathrm{Fe}+{ }_{7} \mathrm{CO}$ or

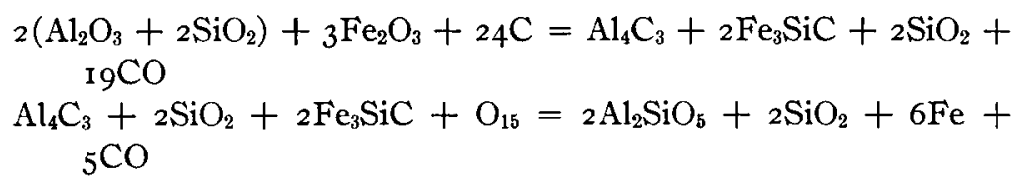
$19 \mathrm{CO}$

$\mathrm{Al}_{4} \mathrm{C}_{3}+{ }_{2} \mathrm{SiO}_{2}+{ }_{2} \mathrm{Fe}_{3} \mathrm{SiC}+\mathrm{O}_{15}={ }_{2} \mathrm{Al}_{2} \mathrm{SiO}_{5}+{ }_{2} \mathrm{SiO}_{2}+6 \mathrm{Fe}+$ ${ }_{5} \mathrm{CO}$

On the assumption that the above equations are all correct it is then evident that $\mathrm{SiC}$ is formed, and that the $\mathrm{SiC}$ gives up the carbon, though not as rapidly as if $\mathrm{SiC}$ were alone. It depends on the ratio of combined carbon and the effect of Si upon the quantity and condition of carbon. When $\mathrm{SiC}$ gives up carbon, leaving behind $\mathrm{Si}$, this ignites spontaneously on coming in contact with the blast, forming first $\mathrm{SiO}$ and then $\mathrm{SiO}_{2}$. The attraction between $\mathrm{Si}+\mathrm{O}$ and then $\mathrm{SiO}+\mathrm{O}$ is very strong, and much heat is produced by the combustion of silicon to silica.

The above equation of the combining reaction of $\mathrm{Si}$ and $\mathrm{Fe}$ is perhaps not the exact chemical combination that might take place, because we have for example ferrosilicon, which shows that $\mathrm{Si}$ is able to unite with $\mathrm{Fe}$ in all proportions. The iron may be absent and in that case more fuel must be added in the cupola. The proportions of the mixture may, however, be varied, as an excess of carbon over the calculated amount of silica is sometimes necessary in order to complete the reaction. The iron when added in the proportion from 3 to 6 per cent, as an ore or as an impure clay, can be mixed with the charge.

It should be made clear that the iron acts as a catalyzer, inasmuch as it accelerates the reaction and promotes more complete reduction of the silica. The iron alloys with the silicon, and it is thus that the silica is separted and volatilized, or sinks to the bottom of the furnace with the iron in the form of pure metallic iron or as ferrosilicon, or alloyed with copper.

When fusion commences in the first hot zone, or layer, reaction is taking place, and $\mathrm{Fe}, \mathrm{Si}$ and $\mathrm{C}$ are set free. Consequently after this first reaction the rest of the reactions take place more rapidly. It is thus the iron which accumulates, as it is not eliminated from the charge by volatilization. It is very desirable that 
titanium be present, as it detains the combination of iron with alumina, and, therefore, the iron can act continuously with the silica when the mass is brought to boiling.

It will be seen that the chemical process must go on continuously and consecutively as each thermic zone may permit it. This is evident because in two or three hours the temperature has reached the stage where the heaviest fumes of silica emerge and the heaviest deposit of $\mathrm{SiO}_{2}$ takes place. This volatilized silica has an apparent specific gravity of 0.47 and is snow-white.

The volatilization of the silica depends upon the total amount of carbon and iron present, and also upon the temperature of formation and perhaps also upon the presence of other elements, to create conditions favorable to dissociating the $\mathrm{SiO}_{2}$ into $\mathrm{Si}$ $+\mathrm{O}_{2}$, and the formation of $\mathrm{SiC}$, which later is broken up when in turn $\mathrm{SiO}_{2}$ is again formed by reoxidation.

From my standpoint, as I conceive this chemical action, it must be evident that the formation of the carbides such as $\mathrm{Fe}_{3} \mathrm{C}$, $\mathrm{SiC}, \mathrm{Al}_{4} \mathrm{C}_{3}$ and $\mathrm{CaC}_{2}$ and others are gradual, and as quick as they are formed they are changed again to oxides. Only the $\mathrm{Fe}$ remains in a metallic state. However, some of it is expelled in the form of magnetite iron $\left(\mathrm{Fe}_{3} \mathrm{O}_{4}\right)$ as fine particles carried out by the blast. The iron which is in a combined state with the material or fused mass is in a magnetic state and, therefore, renders the whole mass almost magnetic.

A very interesting test was made on this subject. We sent some of our material to be tested by magnetic separation to Dings Magnetic Separator Co., Milwaukee, Wis. They found the following results: Laboratory sample 270 (20 mesh).

$\begin{array}{lr}\text { "A" medium magnetic } \ldots \ldots \ldots \ldots \ldots \ldots \ldots \ldots & \begin{array}{r}\text { Per cent } \\ 0.73\end{array} \\ \text { "B" first high magnetic } \ldots \ldots \ldots \ldots \ldots \ldots \ldots & 88.50 \\ \text { "C" second high magnetic } \ldots \ldots \ldots \ldots \ldots \ldots & 6.37 \\ \text { "D" non magnetic. } \ldots \ldots \ldots \ldots \ldots \ldots \ldots \ldots & 4.40\end{array}$

If all the results obtained by my experiments, observations, and my experience in my process are correct, then I freely can state that $\mathrm{C}$ or $\mathrm{CO}$, solid or in gaseous state, does not entirely break up the $\mathrm{SiO}_{2}$ into $\mathrm{Si}+\mathrm{O}_{2}$, but this is rapidly accomplished 
in the presence of $\mathrm{Fe}, \mathrm{Mn}$, or ' $\mathrm{Ti}$. The proper quantity of Si volatilization and carbide formation varies with the nature and amount of impurities contained in the rock or minerals, temperature, and hydroscopic state of the blast.

\section{Operation of the Furnace}

The charging of the furance is accomplished as follows: Figure I represents the furnace and blower. The outside shell of the furnace is of common iron such as an old boiler shell; or an old

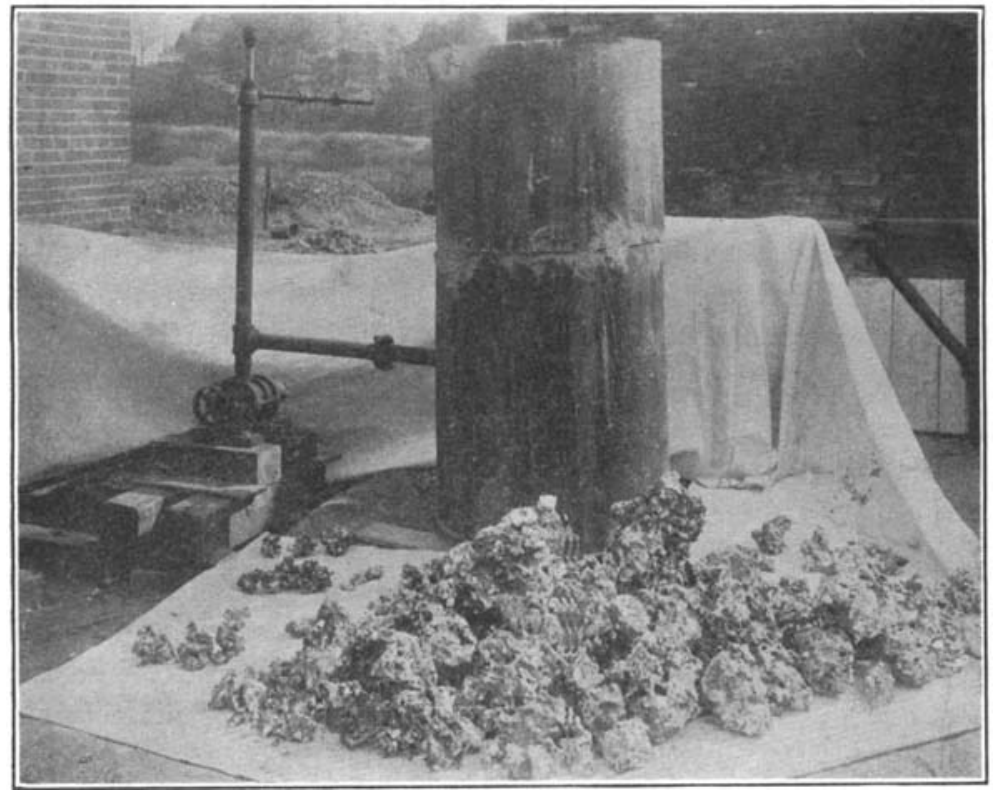

FIG I. - Furnace with blower and fused product.

smokestack can be used. This is lined with good fire bricks. The bricks are then protected with a wall, about 4 inches thick, of the material which is to be fused, crushed fine. A mold is placed inside of the furnace, and the raw material is rammed all around between the inside of the furnace and the mold in a tapering shape, to about one inch thick on top. This will protect the fire bricks from becoming fused and at the same time will pre- 
vent the fused charge from adhering to the fire bricks. Thus the fused mass can be discharged freely in a very short time. When the ramming is finished the mold is removed.

This protection of the raw material which is not mixed with coke is 4 inches thick only to the line where the mass shrinks to its limit. From this line it then tapers gradually to one inch at the top of the furnace. The reason for this arrangement is that when the furnace is fully charged and the heat commences to rise, the charge will shrink and sink down to this line, which is about four feet or so from the top of the furnace. The raw clay which is not mixed with coke or coal, and which I call a protective wall, will fall gradually on top of the charge and will hinder the free passage of the volatilized silica. To avoid this I usually mix the raw clay from that point on with a little coke. The top of the furnace from this line can be removed if so desired in order that the volatilized silica does not cling to the wall and become re-fused in the mass, which is a great detriment. The silica fumes should always pass off freely.

Large lumps of coke are placed on the grate bars for a height of about $30 \mathrm{~cm}$. These big lumps of coke are used in order to protect the grate bars from fusing. Coke is one of the best solid fuels for my process as it does not crush or disintegrate and carries the weight of the charge better than coal. The coke serves also to preheat the air. On top of this coke about $60 \mathrm{~cm}$. small coke is placed, then a little kindling wood, on top of this small coke again about $15 \mathrm{~cm}$. high. Then the fire is lighted and the blower is also run very slowly until a heavy smoke commences to rise. Then the crushed clay mixed with the crushed coke is put into the furnace, and the speed of the blower is gradually increased to furnish about 18,000 cubic feet of compressed air per hour under three pounds pressure.

The steam commences to rise, mixed with heavy smoke, and in about two hours the charge commences to sink down and the gas to burst into flame above the cupola. The rest of the charge, about one-third, is then put into the cupola. The blast of compressed air is forced through the $165 \mathrm{~cm}$. high fuel bed of coke, becomes very well preheated, and is then forced through the hot 
mass, producing combustion. The silica commences to be deposited on the furnace wall. This period is very well characterized by the yellow flame coming from the furnace.

It is very important in my process to have the heat from the bottom of the furnace, and therefore, enough fuel should be placed

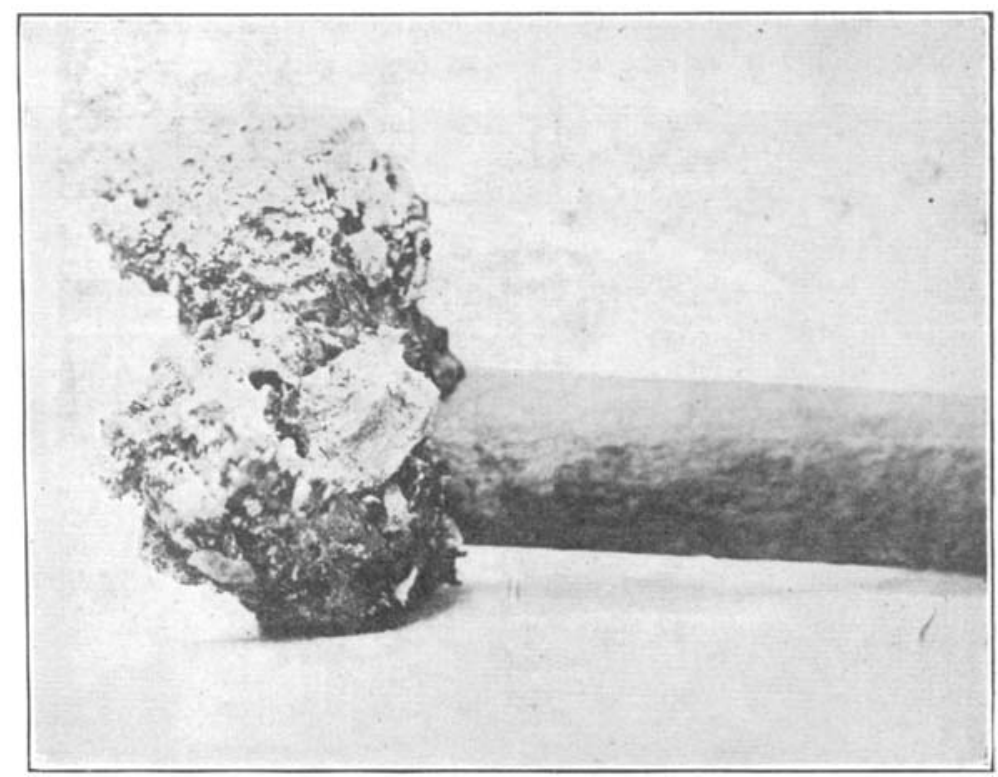

FIG. 2.-Rod, which was immersed in the fused boiling mass, covered with sillimanite crystals.

to last through the whole process. The furnace must be heated under such a reducing condition in the beginning as to convert gradually all the $\mathrm{Fe}, \mathrm{Si}$ and $\mathrm{Al}$ into carbides. It should be understood that reduction takes place only at temperatures where solid carbon takes up oxygen from the material. The quantity of $\mathrm{CO}_{2}$ present inside the furnace is sufficient to retard the process of reduction greatly, while the $\mathrm{CO}_{2}$ is usually too small to be formed by the action of $\mathrm{CO}$ alone on the raw material. These facts point to the probability that there must be a considerable amount of reduction of the material taking place by the action 
of solid carbon in the upper part or zone of the furnace and that the resulting $\mathrm{CO}$ performs an additional reduction in the still higher zone.

To promote or hasten the volatilization of silica from a material of high melting point such as halloysite, bauxite or any other aluminous rock or minerals, fluorspar or cryolite can used. I have found that cryolite is more desirable than fluorspar. Cryolite found in nature or the artificial variety can be used,

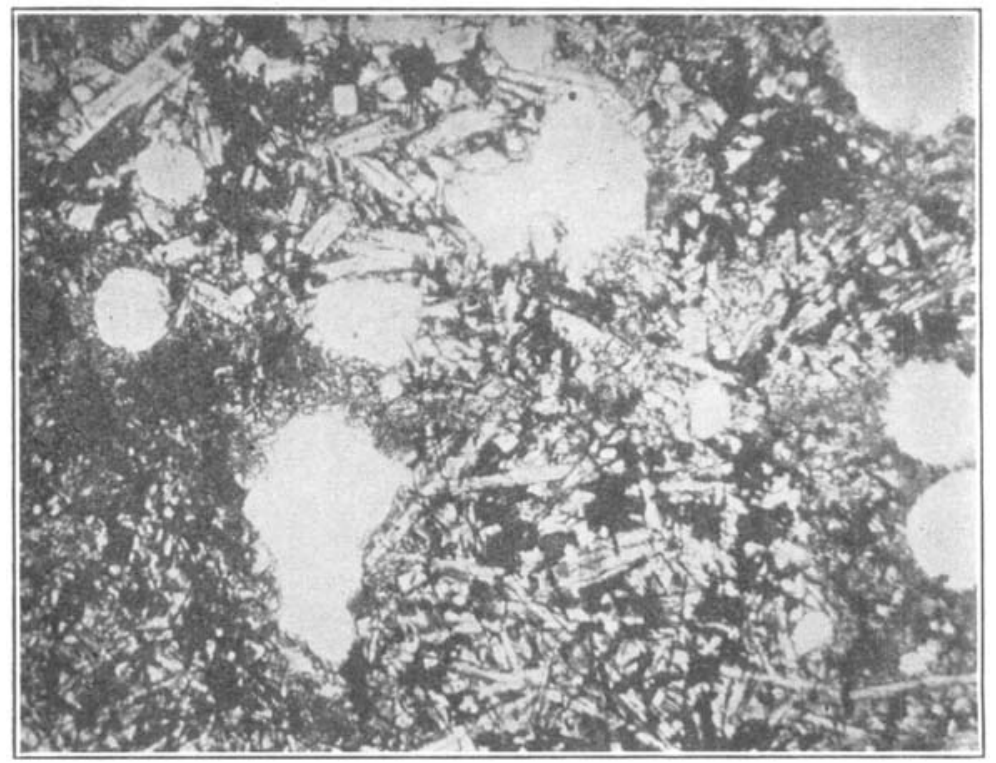

FIG. 3.-St. L. VI. B. taken in ordinary light. Note the development of sillimanite crystals and their variation in size from thin needles to comparatively large prisms. Note also the development and structure of the slag. Magnification- 150 diameters.

or any other fluoride. If cryolite is used the volatilization of the silica is very rapid and the time is considerably shortened. Cryolite is a fluoride of aluminum and sodium $\mathrm{AlF}_{3}+3 \mathrm{NaF}$. The action which takes place in the presence of cryolite with the silica is as follows:

$$
2\left(\mathrm{AlF}_{3}+3 \mathrm{NaF}\right)+{ }_{4} \mathrm{SiO}_{2}={ }_{3} \mathrm{SiF}_{4}+\mathrm{Al}_{2} \mathrm{SiO}_{5}+{ }_{3} \mathrm{Na}_{2} \mathrm{O}
$$


The liberation of the fluorine gas at a very low temperature from the cryolite produces the combination with silica, forming silicon tetrafluoride, which escapes as such in the gas form. During this reaction the raw material commences to break up and will be porous. At the same time the heat is increasing in the furnace,

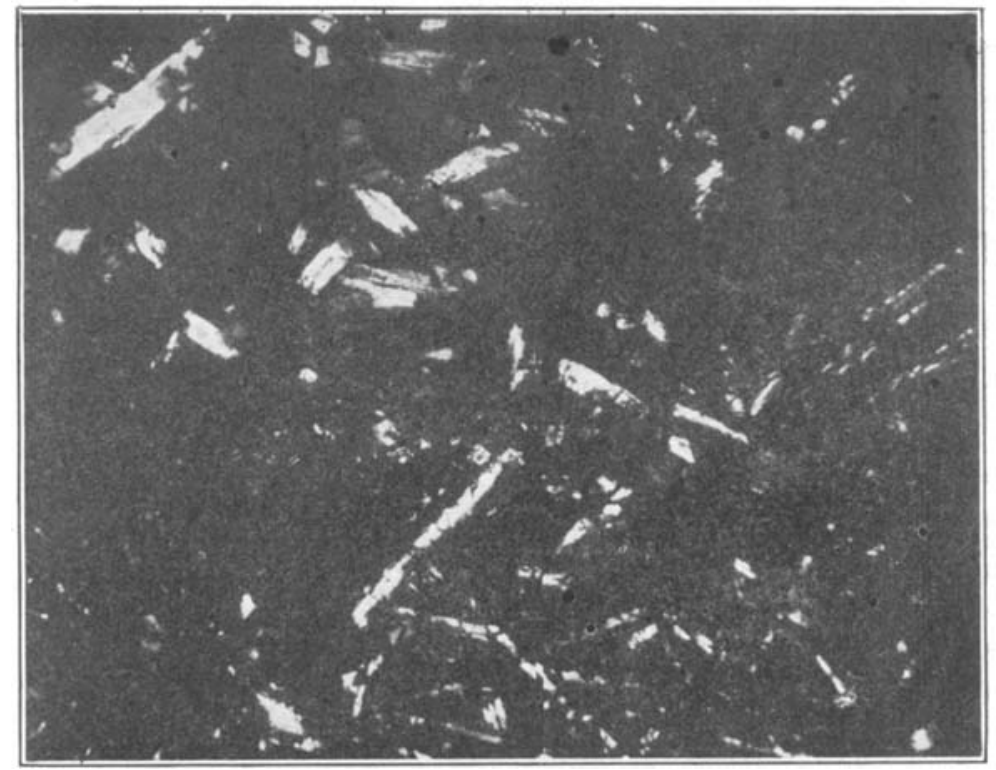

FIG. 4. -St. L. VI. B. taken in plane-polarized light with crossed nicols. Compare with figure 3 . Note the apparent isotropy of the thin sillimanite needles as against the strong birefringence of the thicker prisms.

liberating the carbon which will act more energetically to reduce the silica to silicon. The above chemical equation shows that by using cryolite $\mathrm{Al}$ is introduced and the product is increased by one molecule of sillimanite and one molecule less of the silica has to be driven off. By using cryolite a purer product is insured and this is accomplished in a shorter time. The quantity of cryolite used depends on the raw material and the purpose to which the product is to be put.

After three hours the whole charge is brought to a dazzling, glowing, white heat, the yellow-violet flames indicating the com- 
bustion of $\mathrm{Si}$ to $\mathrm{SiO}$ and then to $\mathrm{SiO}_{2}$, and the mass is then at its thermic action. The mass, or properly the content of alumina and silica, is boiling which fact is noticed by the roaring noise inside the furnace, and the silica is volatilizing in a dense white bluish, and lastly, in brownish fumes, for about two hours. At the end of five hours the whole process is completed, and air is

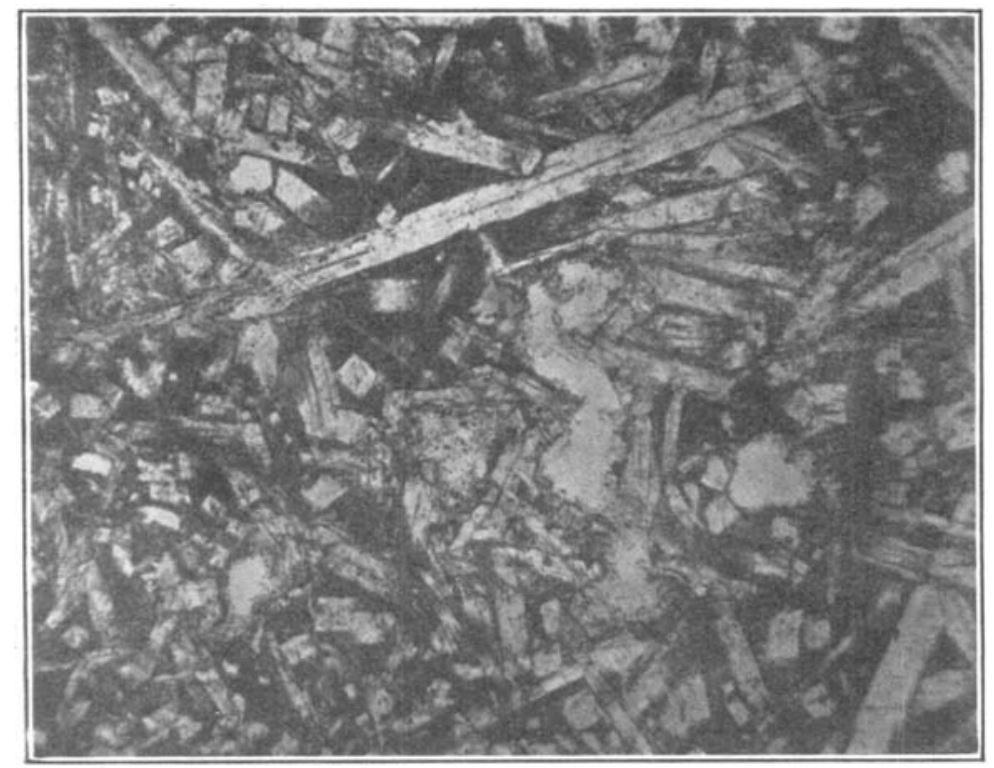

FIG. 5.--Ind. V. B. taken in ordinary light. Compare with figure 6 . Note the size and development of sillimanite crystals imbedded in the interstitial glass and slag. Magnification-I5o diameters.

blown into the cupola through the fused mass in order to produce cells resembling those of diatomacceous earth. The specific gravity of this fused mass varies from 2.62 to 2.86 .

The furnace is provided with an exit pipe through which the fumes and gases are withdrawn and pass through into a settling system, tank, box, room or bags.

The hood can be removed freely to both sides and also lowered or raised. The hood is suspended above the furnace, and a 
vacuum is created so as to collect all the fumes, and by this means the cupola is converted into a half vacuum furnace, or I may. say blast on bottom and vacuum on top. The volatilized silica can be utilized for many useful applications in the arts. Its value is greater than that of the vitreous form.

$\mathrm{By}$ this process and system it should be clear that it is possible to effect a complete separation between the fused mass and alka-

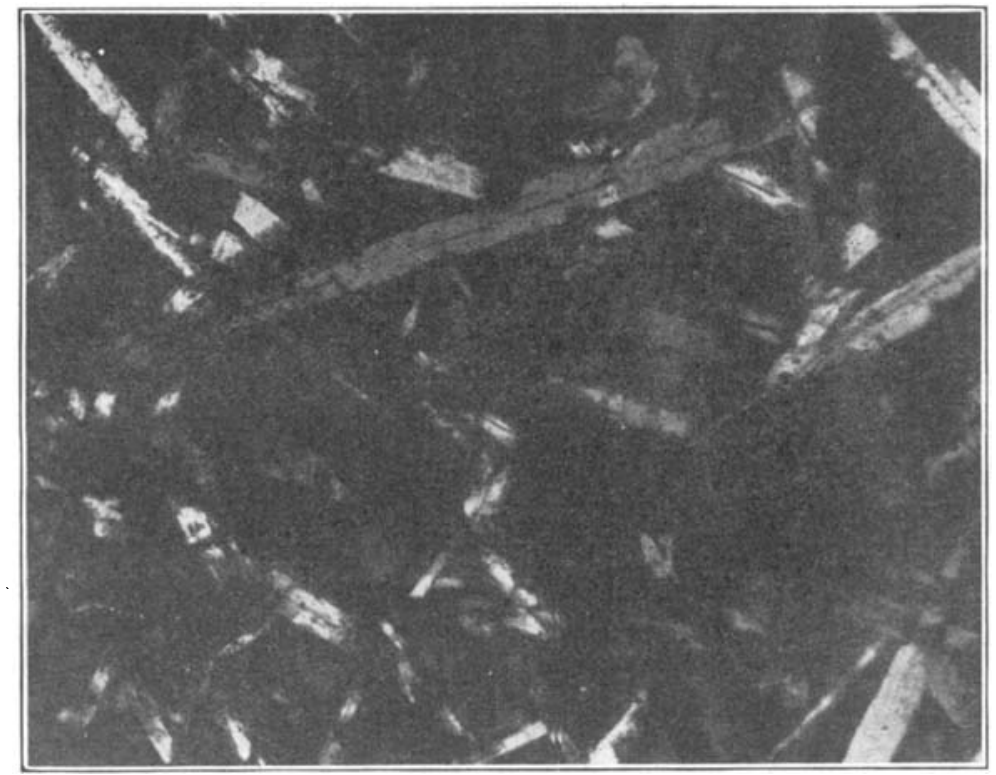

FIG. 6.-Ind. V. B. taken in plane-polarized light with crossed nicols. Note the isotropy of the glass and slag.

lies, and also silica if desired, in a more economical manner than by the use of an electric furnace.

The fused mass can be removed in different ways, the cupola being so designed as to accommodate varying conditions. The mass can be removed at the bottom with the cupola in place, or the cupola can be removed and leave the fused mass standing in place on the grate bars, or the mass and cupola can be removed, and another cupola, already charged, set up on the place, and 
the operations can begin at once. With this system a continuous process is established. You will kindly note that the cupola can be taken apart without interfering with the process. Therefore, if batteries of cupolas are built, the fusion process is not hindered at any stage, and the whole process is more economical, as time is saved and the production is largely increased.

\section{Properties of the Product}

After the mass is removed it is broken up and ground to the required fineness, the iron having been separated out by a magnetic device. It is very interesting to note that almost all the iron and copper collects on the bottom of the fused mass in big nodules. From the top to the center, the mass is almost entirely free from iron and copper. The iron on analysis showed that it is alloyed with silicon, copper and zinc; a small amount of gold was also found.

The fused mass obtained by the process is a product of a very high refractory quality, free from expansion and contraction at any degree of temperature, and it will not warp, crack, nor spall from changing temperature.

Sillimanite so produced by the separation from such a highly viscous magma solution at such high temperature without the addition of any flux is a stable compound of alumina and silica. Research in thermal investigations by many investigators has shown the existence of only one aluminum silicate formed from fused mixtures in crystal form. This is sillimanite, $\mathrm{Al}_{2} \mathrm{SiO}_{5}$, with a melting point of $1815^{\circ} \mathrm{C}$.

It is not necessary to state that fusion tests made on the product of this cupola at different places showed many times that Orton cone 39 , and in one case even cone 40 , was fused and the cone made of the Malinite product remained unaffected. Melting points of cones 36,37 and 38 are common from the fused mass.

Three sample bricks were placed in a high-temperature electric furnace, in contact with the carbon resistor plates. The electric current passed from plate to plate and there was often an arcing action of certain points, which would cause a local temperature of $6300^{\circ} \mathrm{F}$. The furnace temperature was approximately $3000^{\circ}$ $\mathrm{F}$., and under these conditions the Malinite brick was unaffected. 
Our experience with magnesite bricks in this furnace has been that they scale off and disintegrate under the furnace conditions explained above.

Investigations made by different petrologists have demonstrated from different fused masses of different fusions that the crystals present have indentically. the same optical properties as the crystals of sillimanite found in porcelain bodies. The

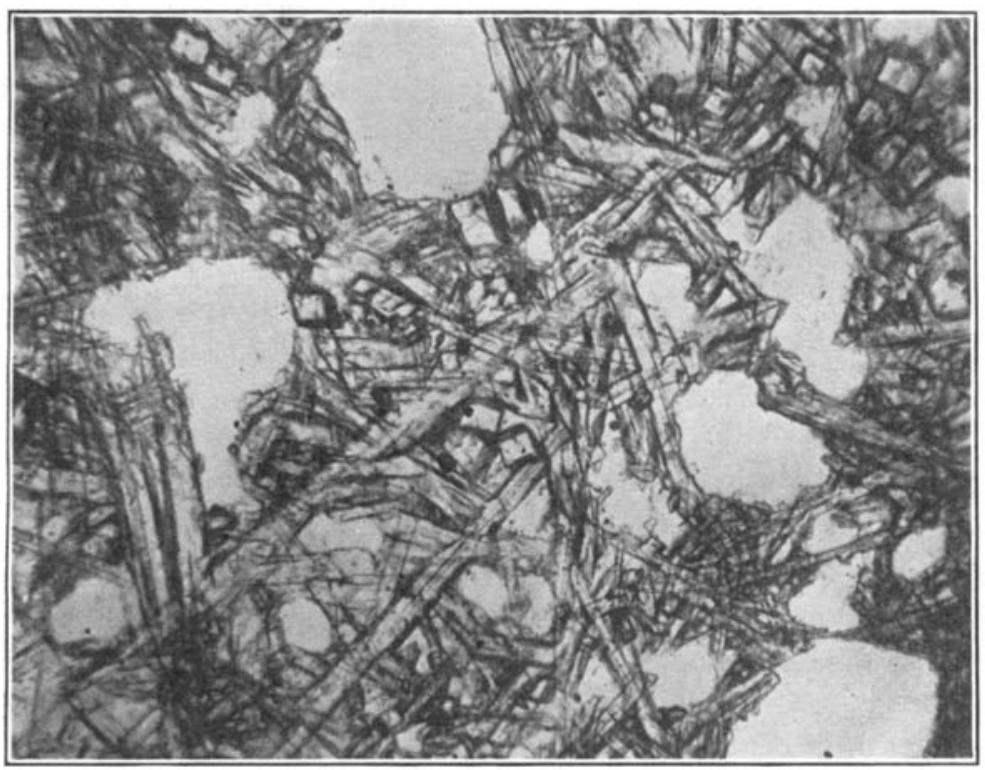

FIG. 7.-St. L. C. II. No. I3 (I) taken in ordinary light. Note the sillimanite coarse crystal development, the int rstitial glass and the almost complete absence of slag. Magnification-150 diameters.

cuts demonstrate the fibrous form of the coarse crystals, aggregates of long unusually strong acicular crystals with parallel extinction and positive elongation. The interference colors are bright.

I have found in this work that the rate at which this crystallization proceeds depends a good deal on the temperature and fluidity of the magma solution from which these crystals develop. It seems to me that the created temperature of the thermal action 
of alumina and silica increases the fluidity of the mass to such an extent that a molecular concentration of alumina and silica takes place, and on cooling from this high temperature the sillimanite separates from the mass. When enough silica is driven off by volatilization and only one molecule of silica is left behind in the mass in proportion to one molecule of alumina, sillimanite will separate out and the mass is converted wholly into sillimanite. If more of the silica remains in the mass, then sillimanite and glass are formed. This glass, however, may be the same composition as sillimanite, but even if it should be fused quartz, it is not a detriment to my product, because sillimanite remains uncombined and will always separate out as such.

Should the magma be siliceous and contain calcium, sillimanite formation is retarded or diminished. In this line I did some very interesting work. I took precipitated alumina, silica and calcium and mixed them in the following proportion:

\begin{tabular}{rrrrrrc} 
& \multicolumn{1}{c}{ A } & \multicolumn{1}{c}{ B } & \multicolumn{1}{c}{ C } & \multicolumn{1}{c}{ D } & E & \multicolumn{1}{c}{ F } \\
$\mathrm{SiO}_{2} \ldots \ldots \ldots \ldots \ldots$ & $36 . \mathrm{I}$ & 35.3 & 34.5 & 33.6 & II.I & 32.2 \\
$\mathrm{Al}_{2} \mathrm{O}_{3} \ldots \ldots \ldots \ldots \ldots$ & 61.5 & 60.0 & 58.6 & 57.3 & 56.0 & 54.8 \\
$\mathrm{CaO} \ldots \ldots \ldots \ldots \ldots$ & 2.4 & 4.7 & 6.9 & 9.1 & 32.9 & 13.0
\end{tabular}

These mixtures were made into small briquets and burned to cone 14, some were burned twice. After they were cool, small pieces were broken off and examinations made under the microscope. These crystals showed different optical properties than was the case in the former fusions; the refractions were not so strong.

When treated with hydrofluoric acid the samples marked $D$, $\mathrm{E}, \mathrm{F}$ were dissolved and a residue of powder left, which on analysis were found to be alumina, calcium and a trace of silica. The silica was almost all volatilized. This demonstrated that the crystals noticed under the microscope were not sillimanite $\left(\mathrm{Al}_{2} \mathrm{SiO}_{5}\right)$ but that they were wollastonite $\left(\mathrm{CaSiO}_{3}\right)$.

The pieces which did not contain lime were not attacked at all by the hydrofluoric acid treatment. The pieces marked from A to $\mathrm{C}$ were a little attacked by the acid.

I also made a very careful study and investigation of the formation of sillimanite with pure kaolin, fire clays and halloysite, but have failed to find sillimanite so far in the above samples 
burned in a commercial kiln. Numerous statements are given and published, in text-books and other literature, that clay decomposes into $\mathrm{Al}_{2} \mathrm{O}_{3}$ and $\mathrm{SiO}_{2}$. LeChatelier, Mellor and Holdcroft; Sosman, Klein and other investigators state that china clay decomposes and gives a product of free silica, alumina and water. The former two, however, are said to recombine in part again to

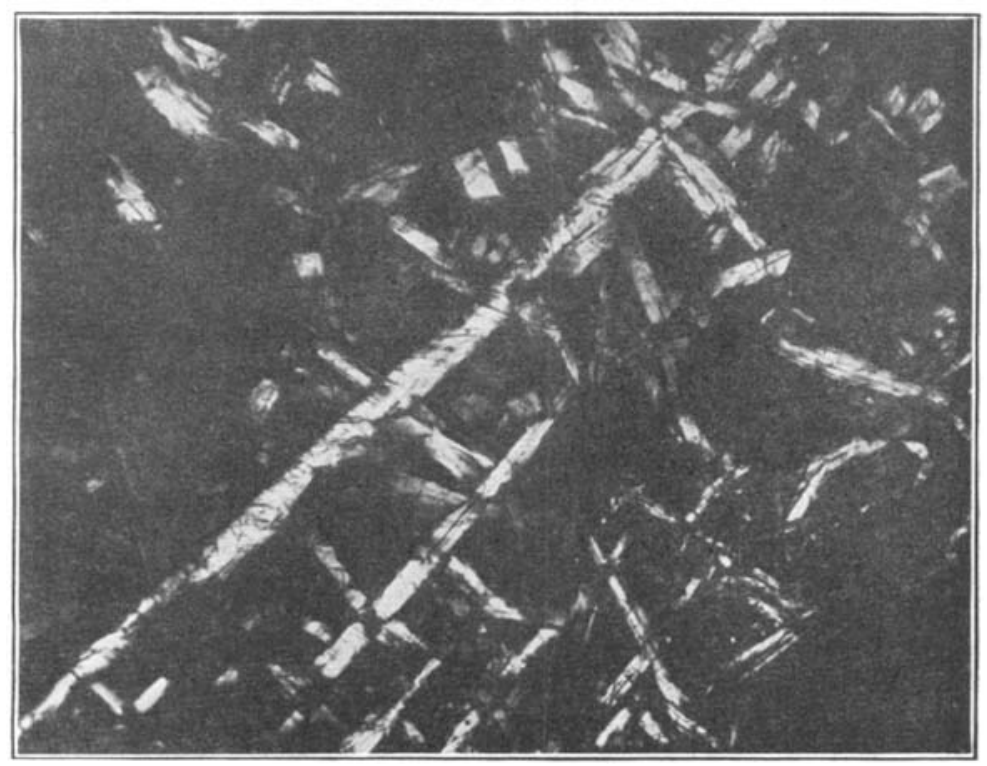

Fig. 8.-St. L. C. II. No. I 2 (1) taken in plane-polarized light with crossed nicols. Compare with figure 7 . This photograph accentuates the difference between the sillimanite crystals and the isotropic glass.

form sillimanite when heated above $1200^{\circ} \mathrm{C}$. I have tried with two different washed kaolins, four different fire clays, and three different halloysites to produce sillimanite. The kaolins were purchased from Roessler, Hasslacher Chemical Company, the halloysites came from Indiana, Georgia and Alabama, and the fire clays from Olive Hill, Mount Savage, Ohio and St. Louis, Mo.

These materials were ground and made up in small briquets of $1 / 4$ inch size, dried and heated to Orton cone 14 for the length 
of 96 hours. After they were allowed to cool, chips were broken off for microscopic examination. No sillimanite was noticed, except in very small pockets in the St. Louis fire clay. A few very fine crystals wete visible with a powerful lens, but they were very uncertain to be sillimanite.

The samples were then placed in the kiln again, on the back wall, and heated four more times to cone 16 , and one time to 18 . After they were allowed to cool to atmospheric temperature, small chips were broken off again and microscopic examinations made. No signs of sillimanite crystals were found in the kaolin, nor in the halloysites, nor in the Olive Hill and Mount Savage clay, but the St. Louis fire clay and also the Ohio fire clay contained a considerable amount of fine crystals in nests scattered throughout the body.

This demonstrates that fire bricks made of pure fire clay, free from alkalies, have to be heated above $1400^{\circ} \mathrm{C}$. in a prolonged heat and then allowed to cool slowly to form a few crystals of sillimanite. The formation of the sillimanite crystals in fire bricks is produced only by prolonged heating at high temperature, and is remarkably better developed in the presence of feldspar minerals and micas in the clay.

Mr. A. A. Klein made a very careful investigation in this line on washed North Carolina kaolin and on English kaolin and found small crystals of sillimanite in the two clays heated in a platinum resistance furnace for five hours between 1400 and $145^{\circ} \mathrm{C} .{ }^{1}$

After I had mixed the raw kaolin, halloysite, and fire clays with 25 per cent feldspar and subjected the mixtures to high temperature, cone 14 for 96 hours, they were allowed to cool and chips were broken off. It was found by microscopic examination that in every sample crystals were noticeable in abundance.

The circumstantial evidence of this work demonstrates that the work done by Vernadsky, Zoellner, Klein and others prove my statements, that in a porcelain body the chief cause of the presence and the separations of the sillimanite crystals from the magma solution, when allowed to cool down slowly from the high temperature of $1400^{\circ} \mathrm{C}$. to ordinary atmospheric temperature, ${ }^{1}$ Bureau of Standards Tech. Paper 80. 
is the solution of the kaolinite by feldspar and more so by orthoclase than by albite. Therefore, in this case kaolin and feldspar are the only essential materials to create conditions for the production of sillimanite crystals.

Vernadsky found that sillimanite crystals are produced whenever mixtures rich in kaolin and feldspar are subjected to a tem-

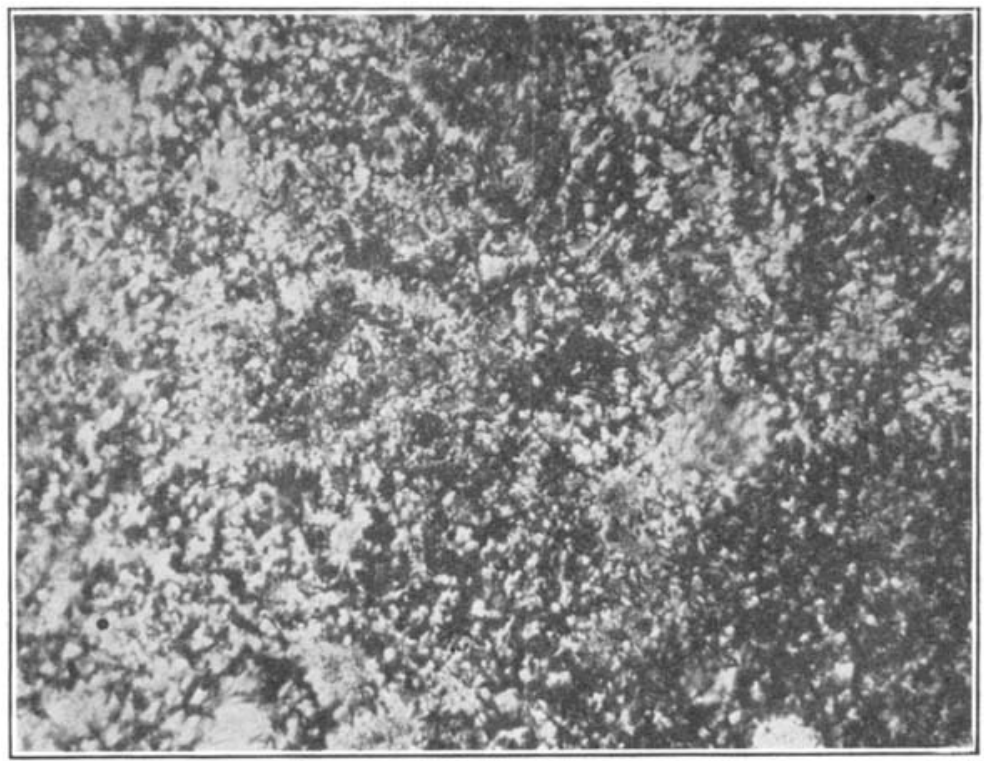

FIg. 9.-St. I. C. II. No. I3 (2) taken in ordinary light. Compare with figure 10. Note the small mainly anhedral sillimanite crystals, the opaque slag and the glass sometimes rendered "muddy" by amorphous sillimanite inclusions. Magnification- 50 diameters.

perature over $1300^{\circ} \mathrm{C}$. The velocity of crystallization of sillimanite in alkaline bodies is governed by time, temperature, and the rate of cooling. In porcelain bodies the slower the cooling the more complete is the process of crystallization, as by this slowcooling process the corresponding chemical composition arranges itself into crystals; a part of the liquid will recrystallize before the remaining magma commences to solidify. In quick cooling of a 
porcelain body or of fire brick the magma solidifies so fast that the chemical components have not the time to form crystals.

In the late work of Albert B. Peck, published in the JournaL of the American Ceramic Society, 2, 75 (1919), he also states, as do Plenske and Zoellner, that the size of the crystals developed appears to be influenced by the three factors; the amount of feldspar or other fluxes present; the mobility of the feldspar, as affected by the temperature of firing; and the length of time of firing. By my process the crystals are developed in a few hours and cooled in about one hour, and unusually large and coarse crystals of sillimanite not known to the present are produced.

Samples subjected to the hydrofluoric acid test have given the following results:

\begin{tabular}{|c|c|c|}
\hline Sample & $\begin{array}{l}\text { Length of } \\
\text { treatment }\end{array}$ & $\begin{array}{c}\text { Per cent } \\
\text { loss }\end{array}$ \\
\hline $19 .$. & I day & 180 \\
\hline $20 .$. & 3 days & 170 \\
\hline $2 \mathbf{I}$. & 6 days & 18.5 \\
\hline 22. & 6 days & 4.0 \\
\hline 23. & 12 days & 5.96 \\
\hline
\end{tabular}

Samples 22 and 23 were chips from the fused product as it came out from the furnace. The average analysis of these two samples was as follows:

$$
\mathrm{SiO}_{2}=37.1 \text { per cent, } \mathrm{Al}_{2} \mathrm{O}_{3}=62.9 \text { per cent }
$$

These crystals once formed are stable and cannot be destroyed in commercial furnaces. But we know that in fire bricks, the bricks become gradually weaker mechanically, as the crystals are formed and the alkalies volatilize. I have noticed in fire bricks made from fire clay, that when they are exposed to repeated heating to high temperatures, and allowed to cool slowly, the small amount of lime which the clay contains does not hinder the formation of sillimanite. But as soon as sillimanite commences to be formed, alkalies and some of the silica commence also to volatilize. The volatilization of silica is especially noticeable in the presence of solid carbon when the furnace is under reducing condition. This applies to all refractories containing silica, even bauxite or flint. 
Therefore, it can be said that all the refractories made from fire clay, flint clay, or bauxite are not stable compounds for linings in furnaces, as they are exposed to continuous expansion and contraction and chemical action. Therefore, their life is limited at prolonged high temperatures at which they suffer mechanical

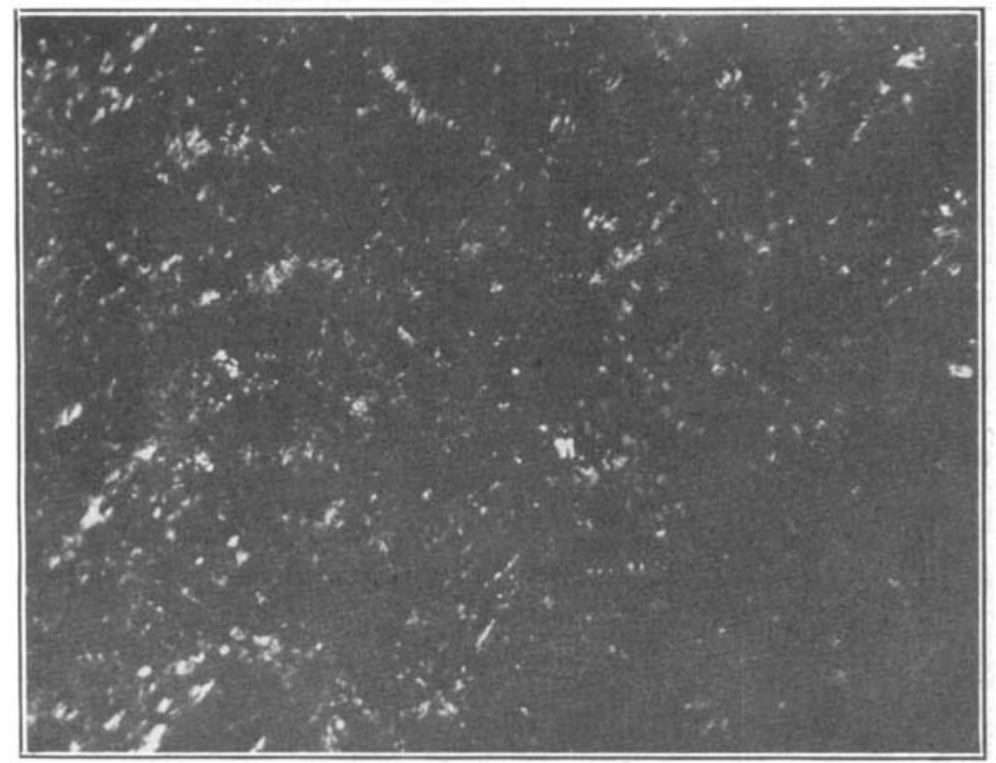

FIG. 10.-St. L. C. II. No. 13 (2) taken in plane-polarized light with crossed' nicols.

destruction. Under the prolonged high temperature, the feldspar mica and lime present in the clay commence to fuse at $1200^{\circ}$ C., as demonstrated by Le Chatelier and Bogitch, forming solutions which cause softening and so dissolve the more refractory substances, leaving cavities for accumulation of ashes, carbon and other substances. This causes further destruction of the brick until they gradually melt away. The vapor of different substances and the volatilized alkalies from the fuel and materials also, cause fluxing actions on the surface of the brick, forming solutions from which the sillimanite is more apt to separate. 
The fused part goes continually deeper and deeper into the brick.

All this crystallization process occurring in the bricks during their use is very irregular and is always accompanied by contraction in volume. At the same time local strains are set up through the whole brick, causing rupture of the brick, or may be the whole wall has to give away. The experimental evidence of the many

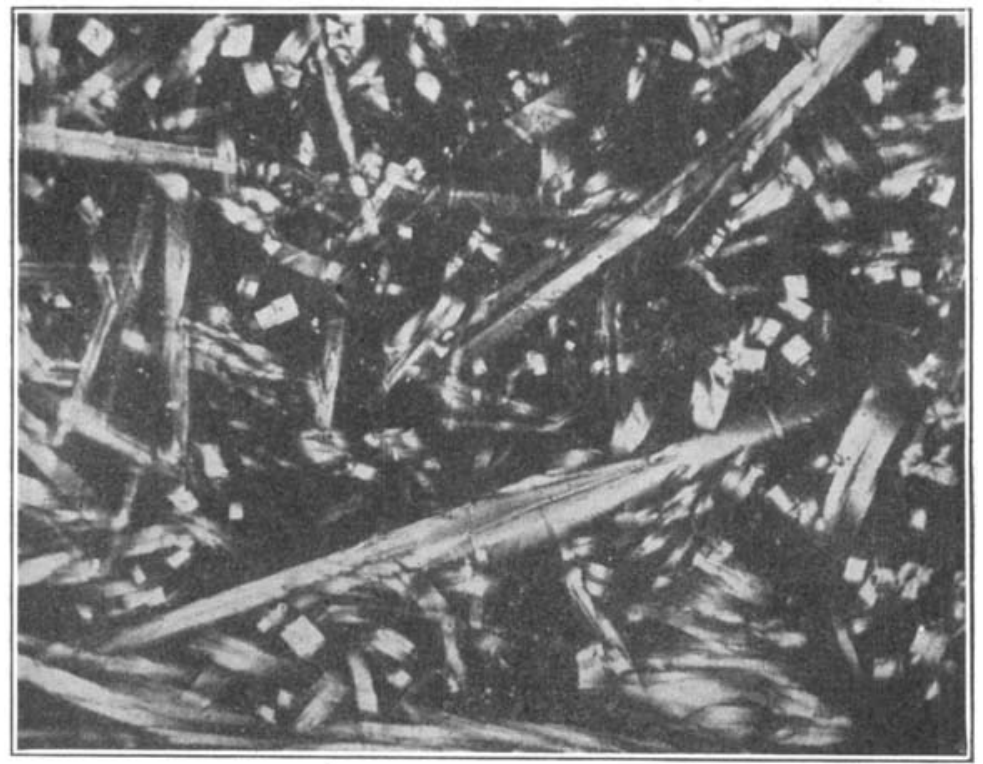

FIG. I1.-St. L. C. III. No. 14 taken in ordinary light. Compare with figure 12. Note the presence of predominating sillimanite and the size as well as the development of the crystals of this constituent. Note also the practical opacity of the glass rendered so by the comparative thickness of the section. Magnification- I 5 diameters.

tests made at different places on Malinite is proof of the stability of the sillimanite crystals produced by my process.

It is of capital importance in the manufacture of refractories to have always a pure uniform material. We know this is very difficult to do with the present methods of working clay; perhaps one strata of the fire clay is very pure while the adjoining 
strata is contaminated with materials which make the clay worthless for refractory purpose. It can be seen that with my process it is very simple to overcome this trouble, and a uniform material is always obtained. Plans can be better and more systematically arranged with a perfect control of the raw material at every point and stage in the manufacturing operations. The variation in raw material from time to time is avoided and the process at every stage is brought under full control.

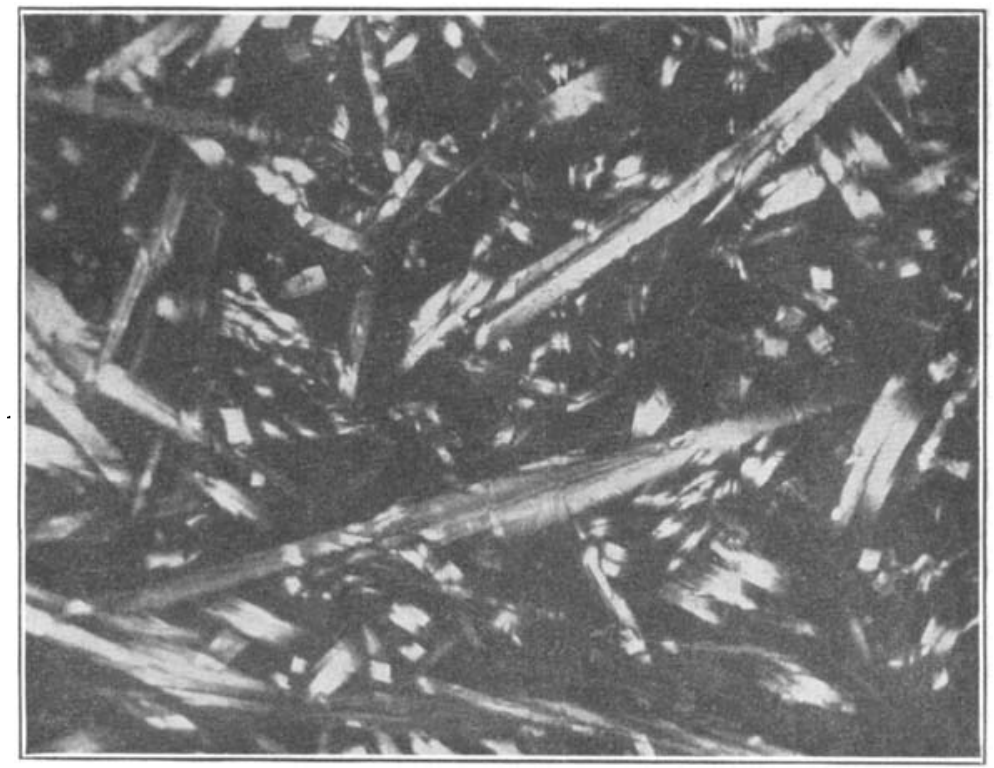

Fig. 12.-St. L. C. III. No. 14 taken in plane-polarized light with crossed nicols.

Here I want to illustrate the analysis of raw and cupola product after the raw materials are fused. The first analysis is from halloysite. You will kindly notice the higher per cent of lime and magnesia, also the presence of some titanium. I am very certain that no titanium is present in this halloysite in the raw state, as I made numerous analyses, I may say thirty or more, and never found titanium. I found cobalt, zirconium and manganese in 
traces, but never titanium. The titanium in this analysis is brought in by the impurities of the coke. We used a coke which showed on analysis 15.50 per cent of ash, called Turkey Knob coke.

\begin{tabular}{|c|c|c|c|}
\hline & $\begin{array}{c}\text { Raw } \\
\text { halloysite }\end{array}$ & $\begin{array}{l}\text { Calculated. The } \\
\text { moisture is omitted }\end{array}$ & $\begin{array}{l}\text { The fused } \\
\text { product }\end{array}$ \\
\hline$\ldots \ldots \ldots$ & 34.06 & $47 \cdot 54$ & 17.16 \\
\hline $\mathrm{Al}_{2} \mathrm{O}_{3} \ldots \ldots \ldots$ & 33.07 & 46.16 & 78.39 \\
\hline $\mathrm{Fe}_{2} \mathrm{O}_{3} \ldots \ldots \ldots \ldots$ & 3.11 & $4 \cdot 35$ & .89 \\
\hline $\mathrm{CaO} \ldots \ldots \ldots \ldots$ & .49 & .68 & I. 50 \\
\hline $\mathrm{MgO} \ldots \ldots \ldots$ & $.4^{2}$ & .59 & .29 \\
\hline Alk.......... & .49 & .68 & 0.36 \\
\hline $\mathrm{TiO}_{2} \ldots \ldots \ldots$ & $\ldots \ldots$ & $\ldots \ldots$ & $\ldots$ \\
\hline Moisture....... & 28.53 & $\ldots \ldots$ & $\ldots \ldots$ \\
\hline
\end{tabular}

St. Louis fire clays which we have received:

\begin{tabular}{|c|c|c|c|}
\hline & 1 & 2 & 3 \\
\hline $\mathrm{SiO}_{2} \ldots \ldots \ldots$ & 47.25 & 52.20 & $53 \cdot 50$ \\
\hline $\mathrm{Al}_{2} \mathrm{O}_{3} \ldots \ldots \ldots$ & 28.22 & 26.92 & 28.75 \\
\hline $\mathrm{Fe}_{2} \mathrm{O}_{3} \ldots \ldots \ldots$ & $4 \cdot 13$ & 2.68 & 3.84 \\
\hline $\mathrm{CaO} \ldots \ldots \ldots$ & .70 & 1.00 & 1.60 \\
\hline $\mathrm{MgO} \ldots \ldots \ldots$ & 1.77 & I .88 & 0.87 \\
\hline Alk......... & .76 & $0.5 \mathrm{I}$ & $\ldots$ \\
\hline $\mathrm{TiO}_{2} \ldots \ldots \ldots$ & $4 \cdot 55$ & $4 \cdot 10$ & 4.10 \\
\hline $\mathrm{H}_{2} \mathrm{O} \ldots \ldots \ldots$ & 3.80 & 10.70 & $7 \cdot 30$ \\
\hline Volatile matter & 8.82 & & \\
\hline
\end{tabular}

In the third analysis the alkaline content is missing, as it was not sought for.

The analysis of the fused product from St. Louis fire clays are as follows:

$\begin{array}{rrrrrr}\mathrm{SiO}_{2} \ldots \ldots \ldots \ldots \ldots \ldots \ldots & 32.60 & 33.10 & 38.10 & 36.30 & 37.50 \\ \mathrm{Al}_{2} \mathrm{O}_{3} \ldots \ldots \ldots \ldots \ldots \ldots \ldots & 63.84 & 63.59 & 56.17 & 58.95 & 57.94 \\ \mathrm{Fe}_{2} \mathrm{O}_{3} \ldots \ldots \ldots \ldots \ldots \ldots \ldots & 1.62 & 1.57 & 2.6 \mathrm{I} & 2.40 & 2.16 \\ \mathrm{CaO} \ldots \ldots \ldots \ldots \ldots \ldots \ldots & .89 & .63 & 1.10 & .65 & .80 \\ \mathrm{MgO} \ldots \ldots \ldots \ldots \ldots \ldots & .32 & .2 \mathrm{~L} & .49 & .22 & .22 \\ \mathrm{TiO}_{2} \ldots \ldots \ldots \ldots \ldots \ldots & .67 & .82 & \mathbf{1} .12 & .95 & 1.10\end{array}$

The specific gravity of the fused mass varies from 2.04 to 2.20 and in some cases to 2.66. The brick, $9 \times 4^{1 / 2} \times 2^{1 / 2}$ inches, weighs 4.280 grams or 9.416 pounds and have an apparent 
gravity of from 2.40 to 2.69. The analysis of the volatilized silica is as follows: $\mathrm{SiO}_{2} 94.5, \mathrm{Al}_{2} \mathrm{O}_{3} 0.50, \mathrm{CaO} 0.60, \mathrm{MgO} 0.5^{\mathrm{r}}$, alkalies 3.67 , and the specific gravity varies from $0.47 \mathrm{I}$ to $\mathrm{I} .875$.

The fused products when removed from the furnace were carefully weighed after every fusion. The charge of raw material placed in the furnace weighed 600 kilograms. The average product taken from the furnace after the fusion was completed weighed 328 kilograms. This contained an average of 40.85 kilograms of iron, which had an average analysis as follows: Si 3.80, Al r.20, Fe 44.86, Ti 49.14, Cu o.09, and C o.89. Many big pieces resembling copper coated with titanium, with a red copper metallic luster, were found. In metallurgy practice it is well known that titanium cyanonitride, $\mathrm{Ti}_{5} \mathrm{CN}_{4}$ is formed in the slag of blast furnaces in which titaniferous iron ore is worked, and that it is found in the form of cubes with copper-red metallic luster.

\section{Microscopic Examination of Samples}

The following is a report made by $\mathrm{Mr}$. A. A. Klein on the microscopic examination of some of the products made by this process.

St. L. VI. $B$ (see figures 3 and 4 ).-This sample was a gray sintered one showing a great number of fine spheroidal pores. The constituents found were sillimanite, glass, slag, and an extremely small amount of amorphous sillimanite.

A study of the microstructure by means of a thin section showed that there were two distinct types depending apparently upon the states of sub-division of the raw materials entering into the product. Such a condition is also found in other types of refractories. That portion of the product formed from coarser raw material contained, in general, fine sillimanite in intergrown fibrous crystals which sometimes were too thin to show double refraction. Amorphous sillimanite was also found here.

The main portion of the sample, however, consisted mainly of crystallized sillimanite occurring in the characteristic long, prismatic crystals which varied in length from under o.or $\mathrm{mm}$. to $0.5 \mathrm{~mm}$. These were embedded in a low refracting, colorless to yellow glass and in a black opaque slag. 
The sillimanite needles which occurred distinctly intergrown and intertwined were longer and thicker than those normally found in porcelain bodies, but their optical constants were identical with those given for artificial sillimanite, namely, $\alpha=$ I.638, $\beta=\mathrm{I} .642$, and $\gamma=1.653$. The character of the principal zone was positive. The extinction was parallel and the inter-

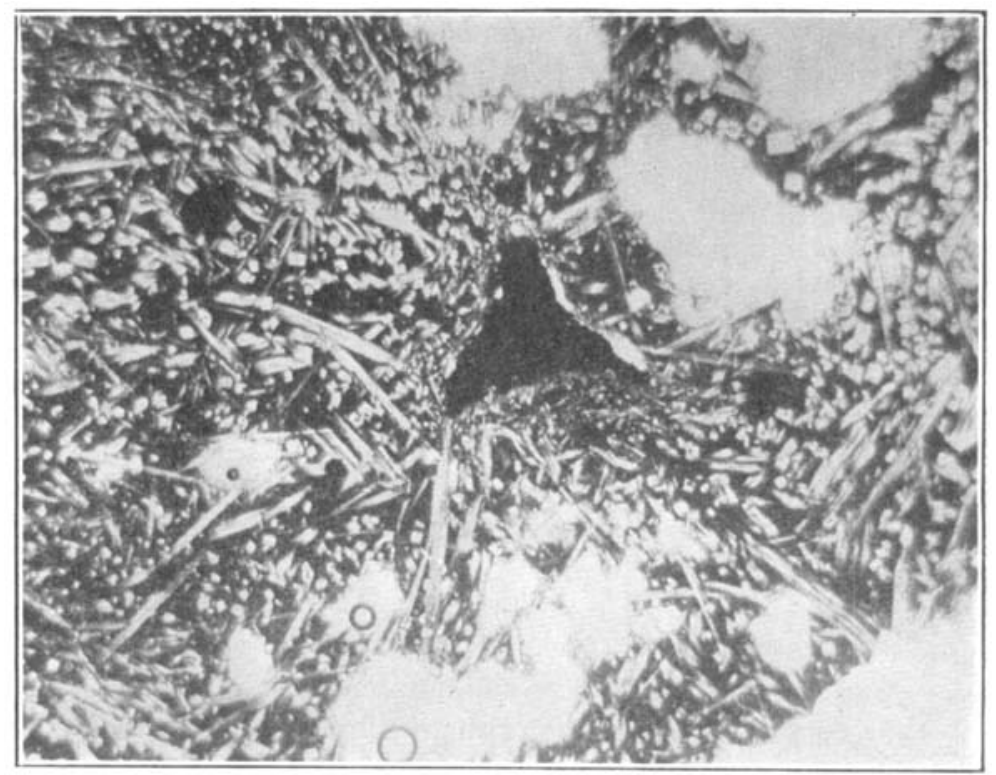

FIG. 13.-St. L. C. III. No. 44 taken in ordinary light. Note the opaque material at the center most of which possesses a metallic luster. This photograph gives a bird's-eye view of the production at low magnification-25 diameters.

ference figures were biaxial with a positive optical character and a small optic axial angle. There was nothing found optically that would indicate another modification of sillimanite, nor even the presence of any great amount of extraneous oxides held in solution.

A quantitative determination of the index of refraction for the glass gave a value for sodium light equal to 1.5 Io \pm 0.003 . The 
opaque slag occurred generally in irregular forms which showed no metallic luster but rather appeared dull in reflected light.

Ind. V. $B$ (see figures 5 and 6).-Visually, as well as microscopically, this sample rather resembled the product previously described. The constituents were sillimanite, glass, slag, and amorphous sillimanite.

As in the case of the previous sample, the microstructure was of two types: first, a uniformly fine crystalline one which was formed from original coarse particles of raw material, and, secondly, the predominant, distinctly coarser crystalline type which was formed from the reaction of materials in a comparatively fine state of sub-division.

The former type generally consisted of very small sillimanite needles which rarely exceeded $0.05 \mathrm{~mm}$. in length and were generally associated with relatively small amounts of amorphous sillimanite. In a few instances, however, the amorphous sillimanite was the chief constituent.

As stated above, the coarser crystalline type was predominant and here the chief constituent was crystallized sillimanite which occurred in a ground mass of colorless glass and opaque slag.

The sillimanite occurred mainly in well-developed crystals of length varying from about $0.01 \mathrm{~mm}$. to $0.08 \mathrm{~mm}$. Optically the crystals were identical with artificial sillimanite. The glass was of a slightly lower index than in the previous sample, the value for sodium light being $1.503 \neq 0.003$.

St. L. C. II (see figures $7,8,9$ and to).-There were two distinct products found in this sample: (I) A white to grayish white vitreous body; (2) a grayish brown sintered product which occurred to a greater extent than (I).

(I) The constituents here were sillimanite with smaller amount of colorless glass and a very small amount of opaque slag.

The sillimanite crystals were well developed and occurred as much intergrown prisms which attained a maximum length of about I mm. Optically, this material agreed with the constants found for artificial sillimanite. In the interstices between the sillimanite crystals and acting as a ground mass for them, oc- 
curred the colorless glass which was present to an extent of at least 30 per cent. The refractive index of the glass for sodium light was $\mathrm{I} .5 \mathrm{I} 4 \pm 0.003$.

(2) The constituents here were sillimanite, amorphous sillimanite, alpha alumina, slag and glass. The sillimanite crystals were generally anhedral, irregular and showed prismatic development to only a slight extent. The largest crystal measured

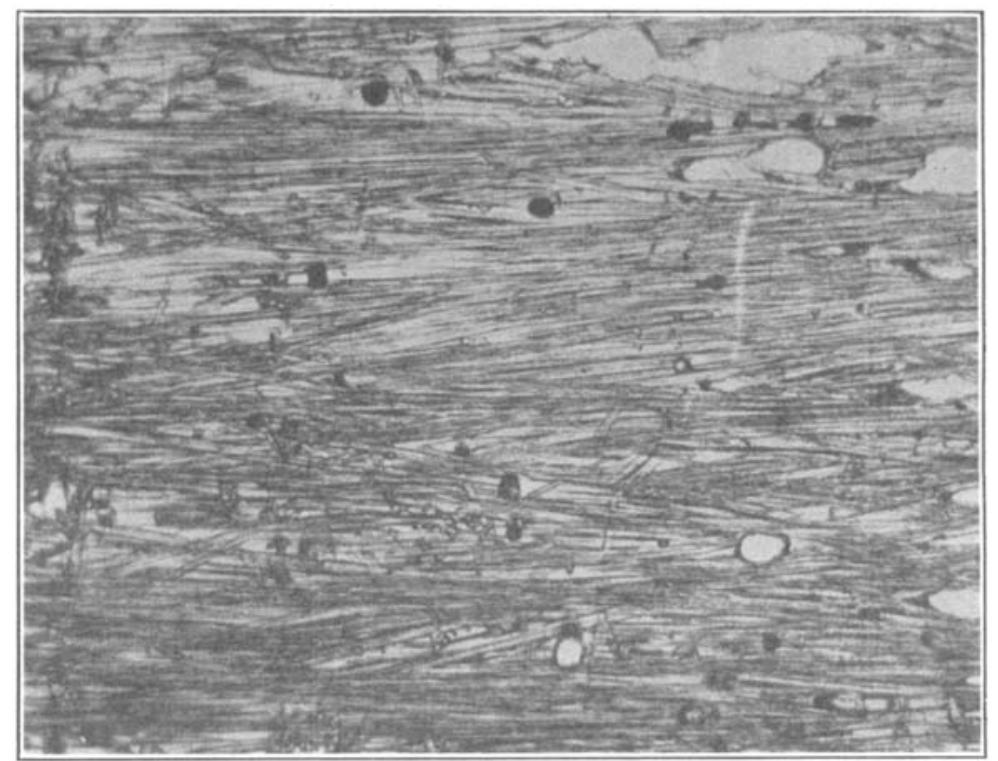

Fig. 14.-I. Ind. taken in ordinary light. Note the extremely coarse crystals of sillimanite and the globules of opaque material Magnification-25 diameters.

under $0.2 \mathrm{~mm}$. in length and most of them were under $0.02 \mathrm{~mm}$. Despite their minuteness and due to their relative thickness, practically all showed double refraction. The refractive indices, which were the only constants that could be obtained with high accuracy, agreed with those given for artificial sillimanite.

About is per cent of alumina was found in small anhedral crystallites intimately associated with the fine crystalline aggregates of sillimanite. Some of these attained o. $\mathrm{mm}$. and in 
all the determinable optical constants agreed with those found for alpha alumina. As in the products previously described, the colorless glass and the slag associated with it occurred as a matrix cementing the crystals of sillimanite and corundum.

St. L. C. III (see figures I 1, 12, and 13).-This sample was a grayish black slag-like product with a stony appearance. It was quite porous, the voids being irregular to spheroidal and

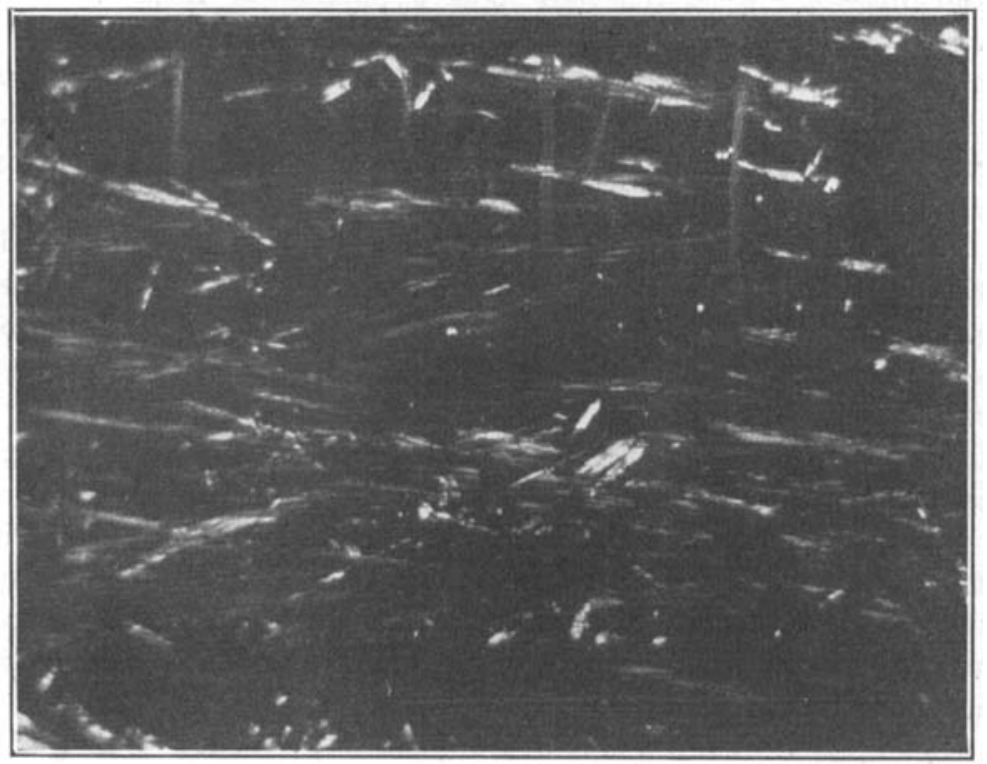

Fig. I5.-I. Ind. taken in plane-polarized light with crossed nicols. Compare with figure 14. Note the two sets of parallel grouped sillimanite crystals one of which is practically in complete extinction.

filled in some instances with thin white to brassy yellow globules possessing a metallic luster. Their chemical composition is unknown but they appear to be at least in part ferrosilicon.

The constituents of the grayish black stony product were sillimanite, glass and the opaque material with metallic luster:

The sillimanite occurred as anhedral long, colorless, prismatic crystals which optically agreed with the data found for artificial 
sillimanite. The crystals varied in size and reached a maximum length of $1.7 \mathrm{~mm}$.

The glassy matrix was colorless to greenish and of a refractive index for sodium light equal to r.5 I0 \pm 0.003 . The slag occurred intimately associated with the glass in the form of minute dusty particles.

The opaque metallic constituent was found in rounded to irregular masses. With reflected light a portion of these at least were found to have metallic luster although in some cases the major portion of the grain was dull. It is impossible to state from this examination just what the actual chemical composition is, except that the material is in part metallic and may, therefore, contain such elements as iron, copper, silicon and so forth.

I. Ind. (see figures $\mathrm{I}_{4}$ and $\mathrm{I}_{5}$ ).- This was a grayish white, fused, vitreous, fibrous product. The constituents were sillimanite, glass and opaque material. The sillimanite was in the form of long, fibrous crystals whose length was limited only by the size of the sections, namely, $8 \mathrm{~mm}$. These fibers showed a tendency toward parallel grouping and in a few instances an angle of approximately $15^{\circ}$ was included between two sets of grouped fibers.

The glass occurred as the matrix between the sillimanite crystals as well as in thin stringer-like inclusions parallel to the long direction of the sillimanite fibers. The refractive index was approximately the same as in some of the products previously described: namely, $1.5^{1} 5 \pm 0.003$.

The opaque material was in the form of extremely small globules, most of which gave decided reflections when viewed in reflected light and are probably of a metallic nature.

The alumina crystals were present to an amount not exceeding a few per cents and are very small. Owing to their minuteness and the fact that they were intimately associated with the sillimanite crystals, their identity was established only through a study of immersed grains since their presence was not apparent in the thin section.

Conclusion.-Owing to the lack of information given it is impossible to discuss and compare the products examined, other than to state that with one exception the chief constituent in 
every case was crystallized sillimanite, that this constituent agreed optically with the constants found for it in previous investigations and that the development as well as the size of crystals was much coarser than that normally found in porcelain and in ordinary refractory clay bodies.

\section{Conclusions}

I. It would be impractically, if not impossible, to convert fire clay into sillimanite by the methods employed in the manufacture of silica and magnesite brick.

2. The microscopic and petrographic examination of the sillimanite developed by my process leads to conclusion that the sillimanite developed by my process, free from any flux, is a stable compound and in comparatively larger crystals than any sillimanite crystals yet produced.

3. No mineral particles remain unaltered. This produces a compound of great resistance against chemical action and thermic changes, whereas in a compound containing unaltered mineral particles continuous alterations will take place, causing spalling and deterioration of the refractories.

\section{Acknowledgments}

The author is forever indebted to Mr. H. H. Randolph for his generous financial support during many years spent in conducting experiments in connection with this work. Also to $\mathrm{Mr}$. Wm. B. Ittner, president of the Malinite Company, who has given financial support for executing the microscopic work, photographs, and lantern slides. My thanks are also due to $\mathrm{Mr}$. John $\mathrm{E}$. Boynton, mechanical engineer, for his aid and suggestions in the work and for his help with experiments. Also to Mr. J. W. Weston, president of the Blackmer Post Pipe Company, of St. Louis, for many good suggestions, advice, and for permission to use kilns for certain experiments, which he helped me to conduct.

'The author also wishes to express his thanks to Professor Rollin D. Salisbury and Mr. Harold W. Tomlinson, and Mr. A. A. Klein for the preparation of microsections, and for the special attention given the examination, microphotographs and reports, 
especially to Mr. Klein, who by tedious work helped to solve the question of the presence of corundum with the fused sillimanite.

The author also wishes to express his indebtedness to Mr. C. W. Hathaway, chief metallurgist of the National Enameling \& Stamping Company, for permission to use the laboratory, microscope and the petrographic camera of that company, and also for his help and suggestions. Also to Mr. J. V. Hartman, chief chemist of the same firm, who checked the analyses, and also confirmed the presence of copper in the iron. And for his help, with that of Mr. H. C. Deterding, in the preparation of the microphotographs of the samples of brick and of the samples after the hydrofluoric acid test.

I am also greatly indebted to Mr. J. H. Campbell, chief chemist and chemical engineer for Robert W. Hunt \& Company, Chicago, for his aid, suggestions and interest for years in this work, for his good advice, and for checking some of my analyses. Also to Professor J. W. Richards for his valuable advice and corrections. 